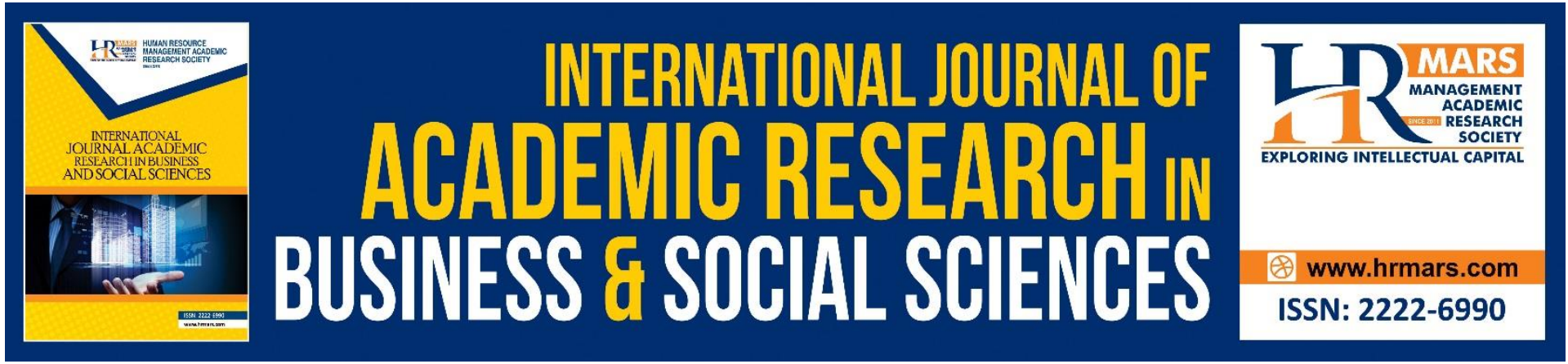

\title{
Financing Pondok Institution Development through Cash Waqf
}

Farahdina Fazial, Surita Hartini Mat Hassan, Sakinatul Raadiyah Abdullah, Che Khadijah Hamid, Salimah Yahaya

To Link this Article: http://dx.doi.org/10.6007/IJARBSS/v11-i7/10519

DOI:10.6007/IJARBSS/v11-i7/10519

Received: 16 May 2021, Revised: 21 June 2021, Accepted: 12 June 2021

Published Online: 20 July 2021

In-Text Citation: (Fazial et al., 2021)

To Cite this Article: Fazial, F., Hassan, S. H. M., Abdullah, S. R., Hamid, C. K., \& Yahaya, S. (2021). Financing Pondok Institution Development through Cash Waqf. International Journal of Academic Research in Business and Social Sciences, 11(7), 618-625.

Copyright: @ 2021 The Author(s)

Published by Human Resource Management Academic Research Society (www.hrmars.com)

This article is published under the Creative Commons Attribution (CC BY 4.0) license. Anyone may reproduce, distribute, translate and create derivative works of this article (for both commercial and non-commercial purposes), subject to full attribution to the original publication and authors. The full terms of this license may be seen at: http://creativecommons.org/licences/by/4.0/legalcode

Vol. 11, No. 7, 2021, Pg. 618 - 625

Full Terms \& Conditions of access and use can be found at http://hrmars.com/index.php/pages/detail/publication-ethics 


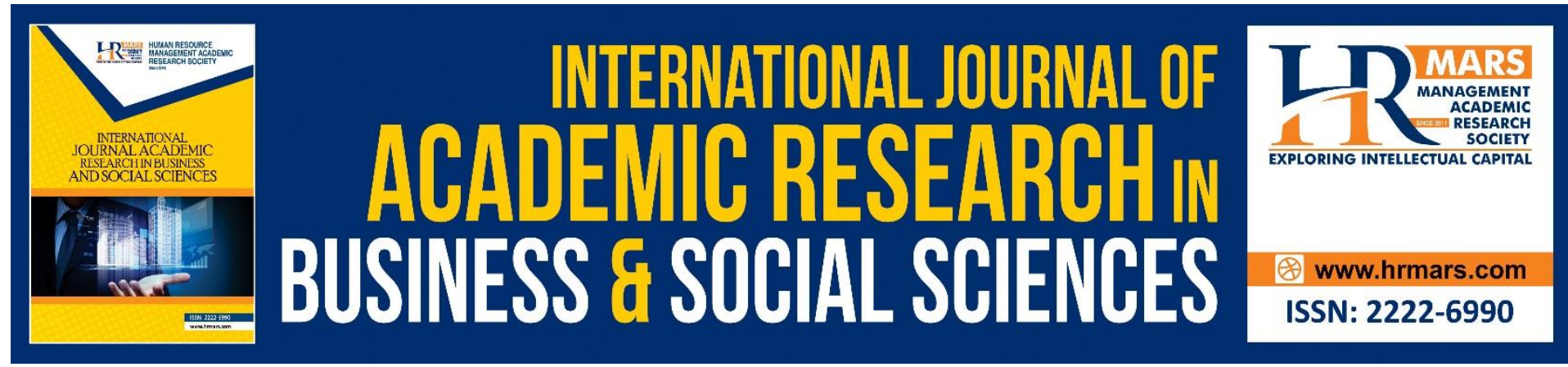

\title{
Financing Pondok Institution Development through Cash Waqf
}

\author{
Farahdina Fazial, Surita Hartini Mat Hassan, Sakinatul \\ Raadiyah Abdullah, Che Khadijah Hamid, Salimah Yahaya \\ Universiti Teknologi MARA Cawangan Terengganu, Malaysia.
}

\begin{abstract}
Waqf plays an important role as a financing instrument for educational institution development. In Malaysia, the majority of the educational waqf institutions focus on the establishment of pondok institutions and religious schools that were built on waqf lands and properties for the purpose of education. Up until today, a number of pondok institutions in Malaysia still rely on public donations for management and administration costs. Using cash waqf as a financing instrument for pondok institution development is seen as an alternative in coping with this issue. Therefore, this research is done to see the suitability of using cash waqf as a financing instrument for Malaysian pondok institution development. This framework uses qualitative research, which involves primary and secondary data. The findings of this research are hoped to reveal the role cash waqf play as a pondok financing instrument in Malaysia.
\end{abstract}

Keywords: Cash Waqf, Financing Development, Pondok Institution

\section{Introduction}

Waqf education is an asset or fund that is given by an individual or organization to an institution and the education sector to continuously finance the management and administration of the institution's development (Ramli \& Hamid, 2014). Not only does this matter eases the community, especially for students seeking to gain knowledge, but also it provides a chance for Muslims to participate in charity. Educational waqf is not something new as it has been enforced since the early Islamic period and has been pioneered by the Middle Eastern and South-East Asian countries such as Egypt, Turkey, and Indonesia. In Malaysia, the enforcement of educational waqf is able to give a significant impact to the lives of the Muslim ummah.

In general, waqf should be built to ensure sustainability from the aspect of educational development financing. Waqf development should be supported with financial income to ensure the waqf assets are generated and maintained properly. The method that can be used is through the generation of revenue from the profit of the waqf project itself or continuous waqf donations from the society. To ensure the sustainability of waqf from a development finance and benefit perspective, the productive usage of waqf is important. Productive waqf refers to the efforts made to expand the waqf wealth productively for the coming generations 
in line with the purpose of the waqf whether the purposes are benefit-or service-oriented (Bahari \& Hassan, 2016). Waqf institutions play a role in using creative financing methods to determine Islamic financing methods towards obtaining financing sources in developing waqf assets. The usage of syariah-compliant and efficient development financing will sustainably maximize the waqf assets benefits as much as possible (Hashim \& Rahman, 2015).

Using cash waqf as one of the productive waqfs in pondok institutions is very significant. This is because the usage of cash waqf as productive waqf is seen as helping the administration to collect funds for the survival of the pondok institution. Collected cah waqf will then be used as fixed assets, which in turn will be invested in order to gain profit. Therefore, this paperwork will examine the application of using cash waqf as the instrument for the pondok institution development financing.

\section{Past Research}

Research conducted by Latiff et al. (2010) listed five potential elements that were emphasized in waqf development in Islamic educational institutions in Malaysia, which are administration management, financial source management, expertise management, management of goals, and marketing management. All these five elements should be updated and taken seriously to ensure the development of waqf for education will be implemented successfully. Besides that, development financing through waqf in Islamic educational institutions such as pondok institutions can be implemented when the community and the pondok administration have a deeper understanding on the generation of waqf, systematic management of waqf by pondok institution administration, effective marketing strategies, and implementation of effective laws (Fazial, 2015).

Harun, Possumah, Shafiai \& Noor (2014) suggested that one of the methods to increase waqf potential is to turn universities into centers for waqf research. This method will inadvertently help increase the usage of waqf in the educational sector. Shukor (2015) is of the opinion that the potential of waqf financing in Higher-Learning Institutions (IPT) such as University Kebangsaan Malaysia (UKM) and University Putra Malaysia (UPM) can be expanded and be advanced. However, financing development for IPT requires continuous cash waqf as an alternative monetary source in handling financial problems in IPT.

Research conducted by Mohsin (2013) found that cash waqf as a source for religious matters may in fact be able to provide necessities for the community such as education, basic infrastructure, commercial activities, and so forth. Practically, cash waqf is seen as a potential alternative worth developing among the Muslims. Physical cash waqf which are portable will make waqf easier to be managed and will make it as a tool to generate and expand waqf to the maximum level (Yon, Latif \& Bahrom, 2008).

Research by Masyita, Tasrif \& Telaga (2005) suggested a cash waqf management system design in a dynamic model system to handle the poverty problem. This dynamic system model requires a large fund to implement planned programmers regardless of financial assistance from the government. Based on the Islamic socio-economic concept, cash waqf is seen as a source of fund accumulation and thus becomes among the best alternative in handling the poverty problem in Indonesia. This suggestion is in line with the research conducted by Kackhar (2017), which stated, in eradicating poverty amongst refugees, the usage of cash 
waqf as a source of micro financing funds is seen as contributing towards the increase in the refugees' socio-economy. Thaker, Mohammed, Duasa and Abdullah (2016) also suggested using cash waqf as micro financing to start and expand businesses. From an economical viewpoint, micro financing will be able to provide work opportunities, increase community income, and so forth. Likewise, Karim (2010) listed five methods used in waqf asset management for financing strategies and management in Singapore, which are using waqf istibdal, internal financing by Baitulmal, Hukr lease, selling available waqf, and external financing such as sukuk musyarakah.

\section{Methodology}

This research involved collecting primary and secondary data. Primary data was obtained through extensive interviews on twelve pondok principals (mudir) who were directly involved in the waqf management and administration of the pondok institution. Mudirs are chosen as informants as they are directly involved with the waqf management in the pondok institution. In this paperwork the informants (mudirs) were labeled with set codes (M001-M012). Extensive interviews were also conducted on two waqf experts PW001 and PW002 to gather extensive information related to cash waqf usage as a financing instrument. Other than that, secondary data was obtained based on past researches and documents. Data was analyzed using the Atlas t.i application version 8 (AV8).

\section{Research Analysis}

Utilization of fixed assets such as cash not only will be able to help strengthen the education system (Nurul Hilmiyah et al., 2013) but will also be able to provide opportunities to the public to participate in waqf according to their ability. Islamic scholars differ in viewpoints with regards to using cash waqf as its basis, and this type of waqf is considered to be invalid when referred to the rule where fixed assets are the basis of the act of waqf. The Indonesian Board of Ulama' (MUI) and pondok scholars are not all in agreement with the practice of cash waqf. Pondok ulama' will only receive the execution of a cash waqf practice when the cash are changed (istibdal) into fixed assets. This matter is still in question even though a number of scholars in Aceh have decreed that cash waqf are still permissible even though they have not been changed to become fixed assets (Mauluddin \& Rahman, 2018).

However, Imam Syafie' is of the opinion that 'every asset that is transactional may be used as waqf as long as the benefits can be reaped by the Muslim ummah'. The concept of cash waqf is a form of contemporary waqf that has the potential for expansion and is intended to raise the number of waqf givers/participants especially in Malaysia. The usage of contemporary waqf intends to ease and encourage the community to perform waqf deeds and to make it the main waqf, seeing this form of waqf is seen as more practical and relevant to be implemented in this era as the collection of cash waqf is more flexible, open, and easier to manage as compared to land and building waqf.

\section{Waqf of Feet (Wakaf Kaki)}

Financing though waqf of feet is one of the schemes in cash waqf. The collection of waqf of feet is normally a method used to collect pondok monetary funds to acquire or purchase waqf property. This scheme has long been practiced by a number of pondok institutions in Malaysia. Waqf of feet refers to the agreement of the waqf giver to purchase land in an area and to waqf the land to a pondok institution. Waqf of feet is seen to lighten the burden of the pondok administration to purchase land or property for development. Other than that, this 
method also allows for community engagement whereby they collectively help in developing the pondok institution itself. Waqf of feet also provides help to the pondok administration to build property besides land acquirement. The community's ability to perform waqf is among the main factors that should be noted by the administration, as there are a number of pondok institutions that are based in rural areas. The following are the types of traditional waqf and contemporary waqf that are accepted by the pondok institutions:

Table 1.1: Types of Waqf Accepted by Pondok Institutions

\begin{tabular}{|l|c|c|}
\hline Pondok & $\begin{array}{l}\text { Immovable Waqf } \\
\text { Asset }\end{array}$ & $\begin{array}{l}\text { Movable } \\
\text { Asset }\end{array}$ \\
\hline M001 & $\checkmark$ & $\checkmark$ \\
\hline M002 & $\checkmark$ & $\checkmark$ \\
\hline M003 & $\checkmark$ & \\
\hline M004 & $\checkmark$ & $\checkmark$ \\
\hline M005 & $\checkmark$ & $\checkmark$ \\
\hline M006 & $\checkmark$ & $\checkmark$ \\
\hline M007 & $\checkmark$ & $\checkmark$ \\
\hline M008 & $\checkmark$ & $\checkmark$ \\
\hline M009 & $\checkmark$ & \\
\hline M010 & $\checkmark$ & $\checkmark$ \\
\hline M011 & & $\checkmark$ \\
\hline M012 & $83 \%$ & \\
\hline Total & \\
\hline
\end{tabular}

Sources: Interview and Atlas ti

Based on the table above, 83 percent of pondok institutions accepted both types of waqf, namely immovable waqf asset and movable waqf asset. 67 percent of pondok institutions accepted both types of waqf. The main factor for a high amount of fixed assets in pondok institutions ( $83 \%$ ) was because the traditional communities gave more waqf on immovable assets such as land, mosques, prayer rooms, and buildings to build pondok institutions. However, these days, the community found it easier to perform waqf through immovable assets, as it is easier and more affordable to perform waqf deeds to help the development of pondok institutions. Movable asset not only used for the development of the pondok institution but also used to develop the pondok economy. Therefore, it can be summarized that almost all pondok institutions received both forms of waqf, which were immovable assets waqf and movable assets waqf.

In general, the concept of cash waqf refers to the freezing of a specific amount of money permanently and the benefits are used for the welfare of the community. This freezing refers to the maintenance of the specific amount of cash and at the same time the waqf management team is to grow it so that the benefits of the waqf assets can be enjoyed by the community as a whole. Due to this, the benefits of the waqf will not emerge by themselves if they are not invested. This method indirectly ensures the actual risk of devaluation. The concept of cash waqf is split into two, which are through ain (waqf shares) and badal, which are waqf of feet (wakaf kaki) and waqf shares. For cash waqf done though badal, the cash collected will be converted to ain (fixed assets). 


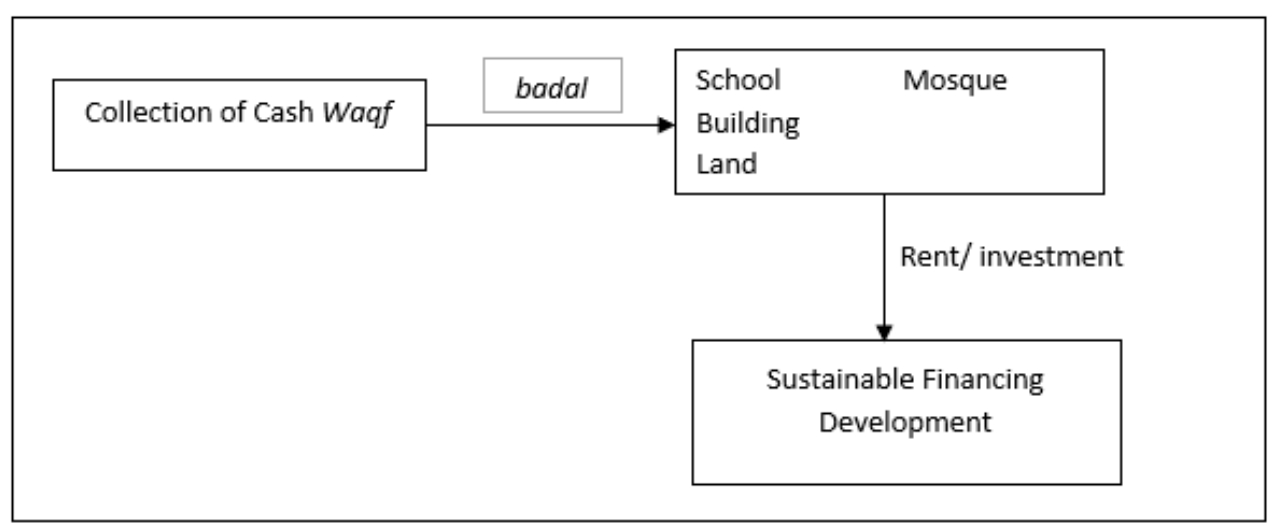

\section{Diagram 1.1: Financing Pondok Institution Development Through Cash Waqf}

Based on Diagram 1.1 above, it was shown that the collection of cash waqf was collected by mutawalli. The total waqf cash collected was then converted into fixed assets such as buildings, schools, shop houses, mosques, prayer rooms, hotels, and others. Waqf buildings built can be rented out or used as an investment asset may indirectly be used as a sustainable development financing for pondok institutions.

This matter was also seconded by M001 who highlighted that the waqf donations received from the community were used for building property in the pondok area. The property built through the cash waqf was then rented out to the Tadika al-Hidayah party. Through the rental charges, the pondok institution was able to generate continuous profit. Seeing the available potential, the pondok institution management was convinced and optimistic to turn the waqf property rental as the main source of income for the pondok institution. This matter is in line with the statement made by Ahmad (2008) and Sayyin (2011) where they stated that cash waqf are funds given to the legitimate management entity to be collected and used as capital to convert the funds into fixed assets and to finance activities related to waqf. The usage of cashnwaqf was seen to ease the educational institution's side in receiving the financing for educational development. The management of the educational institution was responsible to ensure the cash waqf collection received was converted into fixed assets such as schooling property, prayer rooms, and other developments.

Collection of cash waqf also helped pondok management to acquire waqf assets such as land and waqf property to be turned into pondok economy generating assets. PW001 stated that cash waqf collected by pondok institutions were converted into properties such as shop houses, rental buildings, cooperative shops and various other buildings. Through the cash waqf received, pondok institutions will not only be able to add to their waqf assets but also be made into investment assets for sustainable development financing. This sentiment is also echoed by $\mathrm{M008}$ who also applies the usage of cash waqf for sustainable development financing. Cash waqf collection received was changed into cooperative shops not only to help the pondok institutions in generating income but customers were also indirectly helping to donate towards the advancement of the pondok. Other than that, the cash waqf can also be used as a source of micro financing which will be able to assist the institution or community to start and expand businesses (Thanker, Mohammed, Duasa \& Abdullah,2016; Kachkar 2017). From an economical viewpoint, micro financing offers employment opportunities as well as increased income output in the community especially those in and around the stated area. 
Based on the two statements above, a few pondok in Malaysia have made cash waqf as their source of pondok development financing through purchasing waqf land and the building of waqf properties. This method was seen to have high potential for development and execution by other pondok institutions.

\section{Conclusion}

In this modern age, cash has functioned as a medium of exchange; therefore, it is very suitable and effective to perform waqf in cash. The efforts to restore the golden age of waqf can be seen through the changes in the shape of traditional waqf morphing into contemporary waqf. Though this innovative step, waqf is no longer seen as a need among the ummah for life after death such as cemetery waqf, mosques, and religious schools alone. Utilization of cash waqf will not only help pondok institutions in the aspect of financing but may indeed empower the concept of waqf within the pondok administration itself.

\section{References}

Ahmad, A. (2008). Perlaksanaan wakaf tunai oleh Yayasan Wakaf Malaysia (YMT). Jurnal Pengurusan JAWHAR, 2 (2).

Bahari, Z., \& Hassan, S. H. M. (2016). Pembangunan Wakaf Produktif. Kes kajian di Pulau Pinang. Paper presented at Koferensi Internasional Pembangunan Islam 3, Universitas Jember, Jawa Timur, Republik Indonesia.

Fazial, F. (2015). Penjanaan Pembiayaan Pembangunan Pondok AnNahdhoh (PAN), Kubang Semang, Pulau Pinang. Unpublished Master's Thesis. Universiti Sains Malaysia, Pulau Pinang.

Harun, F., M., Possumah, B. T., Shafiai, M. H. M., \& Noor, A. H. M. (2014). Empowering higher education institution: The role of waqf- Malaysian perspective. Paper presented at Australian Academy of Business and Social Sciences Conference.

Hashim, H., \& Rahman, A. A. (2015). Pembiayaan pembangunan harta wakaf menggunakan sukuk. Universiti Malaya.

Hilmiyah, N., Shafiai, M. H. M., Ahmad, S., \& Hariff, M. R. C. (2013). Wakaf Produktif dalam Pembangunan Pendidikan: Kajian di Pondok Moden Darussalam Gontor, Indonesia. Prosiding PERKEM viii, jilid 3, 1302-1314 ISSN: 2231-962X

Mohsin, I. A.(2013), Financing through cash-waqf: a revitalization to finance different needs, International Journal of Islamic and Middle Eastern Finance and Management, 6(4), 304-321

Kachkar, O. A. (2017). Towards the establishment of cash waqf microfinance fund for refugees. ISRA International Journal of Islamic Finance, 9(1).

Karim, S. A. (2010a). Contemporary Shari"ah compliance structuring for the development and management of waqf assets in Singapore. Kyoto Bulletin of Islamic Area Studies.

Latiff, A. Z. A., Ramli, A. H., Ismail, C. Z., Sulaiman, K., \& Daud, N. M. (2008). Pengurusan harta wakaf dan potensinya ke arah kemajuan pendidikan umat Islam di Malaysia. Jurnal Pengurusan JAWHAR, 2 (2).

Masyita, D., Tasrif, M., \& Telaga, A. S. (2005). A dynamic model for cash waqf management as one of the alternative instruments for the poverty alleviation in Indonesia. Paper presented at the $23 \mathrm{rdm}$ International Conference of The System Dynamics Society Massachussets Institute of Technology (MIT). Boston 
Mauluddin, M. I., \& Rahman, A. Ab. (2018), "Cash Waqf From the Perspective of Majelis Ulama Indonesia (MUI) and the Scholars of Aceh", Rahman, A.A. (Ed.) New Developments in Islamic Economics, Emerald Publishing Limited, pp. 49-66

Thaker, M. A. M. T., Mohammed, M. A., Duasa, J., \& Abdullah, M. A. (2016). Developing cash waqf model as an alternative source of financing for micro enterprises in Malaysia. Journal of Islamic Accounting and Business Research, 7( 4)

Ramli, R. N. A. R., \& Hamid, N. A. A. (2014). Kelestarian wakaf dalam membangunkan institusi pendidikan: Kajian awal. Paper presented at International Conference on Postgraduate Research 2014 (ICPR 2014). Proceeding of International Conference on Postgraduate Research (ICPR 2014) (e-ISBN 978-983-3048-98-4.)

Sayyin, B. (2011b). Hala tuju wakaf tunai. Selangor: Pusat Penerbitan Universiti (UPENA), Universiti Teknologi Malaysia

Shukor, A. S. A. (2015). Potensi wakaf pendidikan tinggi di Malaysia. Dewan Bahasa dan Pustaka.

Yon, W. A. W., Latif, M. S. A. A., \& Bahrom, H. (2008). Makanisme wakaf: Gagasan awal terhadap pembangunan dan pembiayaan pusat penyelidikan dan perkembangan Islam Borneo. Jurnal Pengurusan JAWHAR, 2 (2) 